\title{
Landscape Stories. Racconti visuali sul paesaggio del quotidiano
}

\author{
Camilla Casonato \\ Gloria Cossa
}

Abstract

La narrazione è un processo centrale nella raccolta di conoscenze sul paesaggio e sui valori culturali in esso racchiusi, in particolare nei percorsi di valorizzazione rivolti ai luoghi della vita quotidiana che richiedono un processo interpretativo collettivo basato sul dialogo interculturale e intergenerazionale. II saggio fa riferimento a un'esperienza di ricerca sul campo che ha coinvolto studenti della scuola primaria e secondaria in un processo di scoperta, interpretazione e comunicazione del patrimonio culturale materiale e immateriale racchiuso nel paesaggio delle periferie urbane. II testo propone una riflessione sulle diverse forme di narrazione che hanno supportato i percorsi, in particolare quelle di natura visuale e che implicano l'utilizzo dei new media (mappe di percorso analogiche e digitali, mappe mentali, diari di bordo, video, digital storytelling, serious games). Attraverso le attività previste dal progetto, studenti anche giovanissimi sono entrati in contatto in modo diretto, esperienziale e intuitivo con modalità di racconto e descrizione del paesaggio e del patrimonio culturale molteplici, avvicinandosi ai linguaggi disciplinari della rappresentazione architettonica e paesaggistica e scoprendo le diverse potenzialità euristiche e comunicative dei metodi e degli strumenti (analogici e digitali).

Parole chiave

narrazione, ICT, New Media, educazione al paesaggio, rappresentazione partecipata.

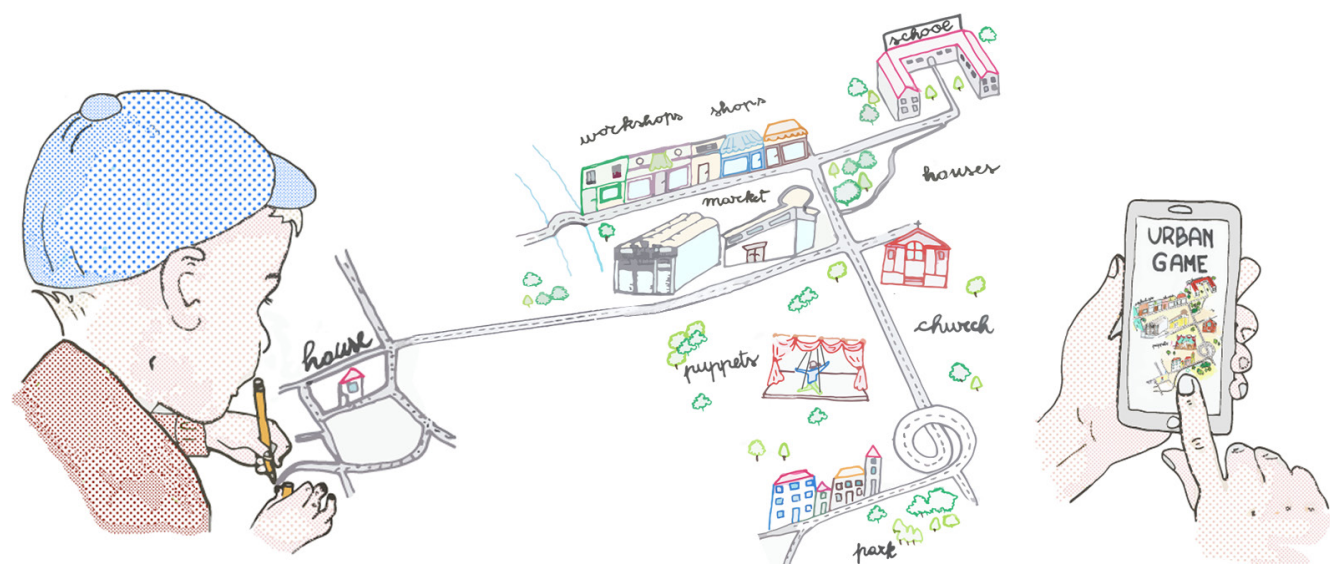




\section{Educazione al paesaggio, narrazione e visualità}

La narrazione è un processo centrale nella raccolta di conoscenze sul paesaggio e sui valori culturali in esso racchiusi. Trovare strategie, strumenti e metodologie per costruire un racconto condiviso dei luoghi è essenziale, in particolare, nei percorsi che si rivolgono al paesaggio della vita quotidiana, i cui valori possono essere messi in luce solo attraverso un processo interpretativo collettivo [Bortolotti et al. 2008; Branchesi 2007; Calcagno Maniglio 2017; Derr et al. 20 I8].

II presente saggio fa riferimento all'esperienza di un team interdisciplinare di ricerca del Politecnico di Milano impegnato in un processo biennale di sviluppo e sperimentazione di metodologie e strumenti di educazione al paesaggio nelle scuole delle periferie urbane. II progetto "Scuola Attiva Risorse (ScAR)" è stato finanziato nell'ambito del programma Polisocial e ha coinvolto nel biennio 20 I 8-2019 oltre seicento studenti dalla scuola primaria alla secondaria di secondo grado in un processo di scoperta, interpretazione e comunicazione del patrimonio culturale materiale e immateriale racchiuso nel paesaggio. All'interno del progetto si sono combinate attività di tipo tradizionale (anche se non sempre consuete per la scuola) e attività che prevedono l'uso delle tecnologie. Ai percorsi nei quartieri e alla raccolta di testimonianze, si sono associati il disegno di paesaggio, la mappatura delle esperienze, la costruzione di plastici dei quartieri, la riflessione progettuale sugli spazi aperti. L'introduzione delle ICT nei processi ha consentito di sviluppare prodotti specifici di comunicazione, dalla mappatura digitale, alla costruzione di guide turistiche multimediali, allo sviluppo di serious games. Alla luce di questo percorso si intende qui proporre una riflessione tematica sull'esperienza, focalizzando l'attenzione su alcune delle diverse forme di narrazione che hanno supportato i processi, in particolare quelle di natura visuale e che implicano l'utilizzo dei new media.
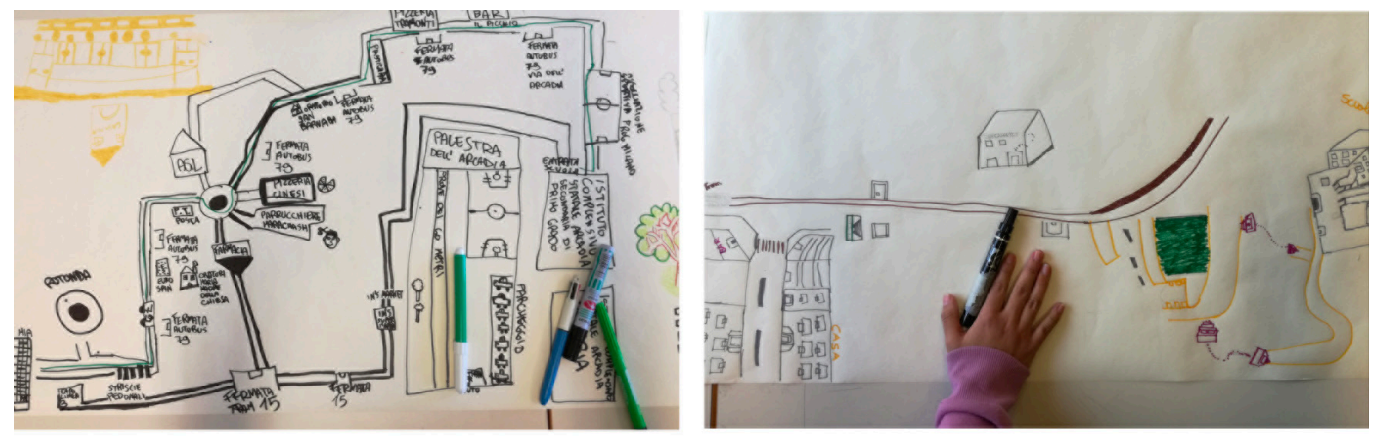

Fig. I. Mappe mentali del percorso casa-scuola realizzate dagli studenti di una scuola secondaria di primo grado.
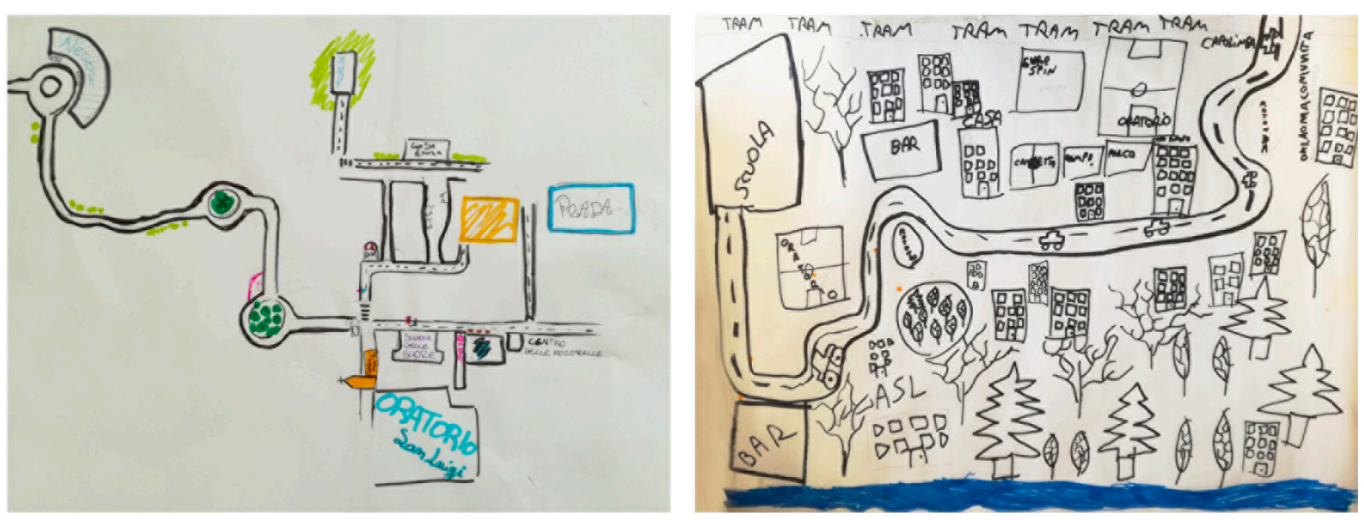


\section{Mappe e disegni per raccontare l'esperienza dello spazio urbano}

Esiste una vasta tradizione di costruzione di rappresentazioni territoriali partecipate e finalizzate al racconto dell'esperienza dei luoghi. Tale tradizione è legata in buona parte ai processi educativi: esempi interessanti in questo senso sono presenti in ambito anglosassone [Derr 20 18; Sobel 1998] e francese, come dimostra l'azione educativa sistematica operata dai Conseils d'Architecture, d'Urbanisme et de l'Environnement. Un contesto di riferimento altrettanto interessante è rappresentato dai processi collettivi di costruzione di conoscenza tipici dei musei di comunità e dei programmi di cooperazione allo sviluppo [Burini 2007; Burini 20I3; IFAD 2009].

Fig. 2. Immagini tratte dal diario di bordo di una studentessa di seconda media che racconta del desiderio di rendere abitabili gli alberi del suo quartiere e progetta un suolo urbano con un "verme virtuale" che la segue per la città.
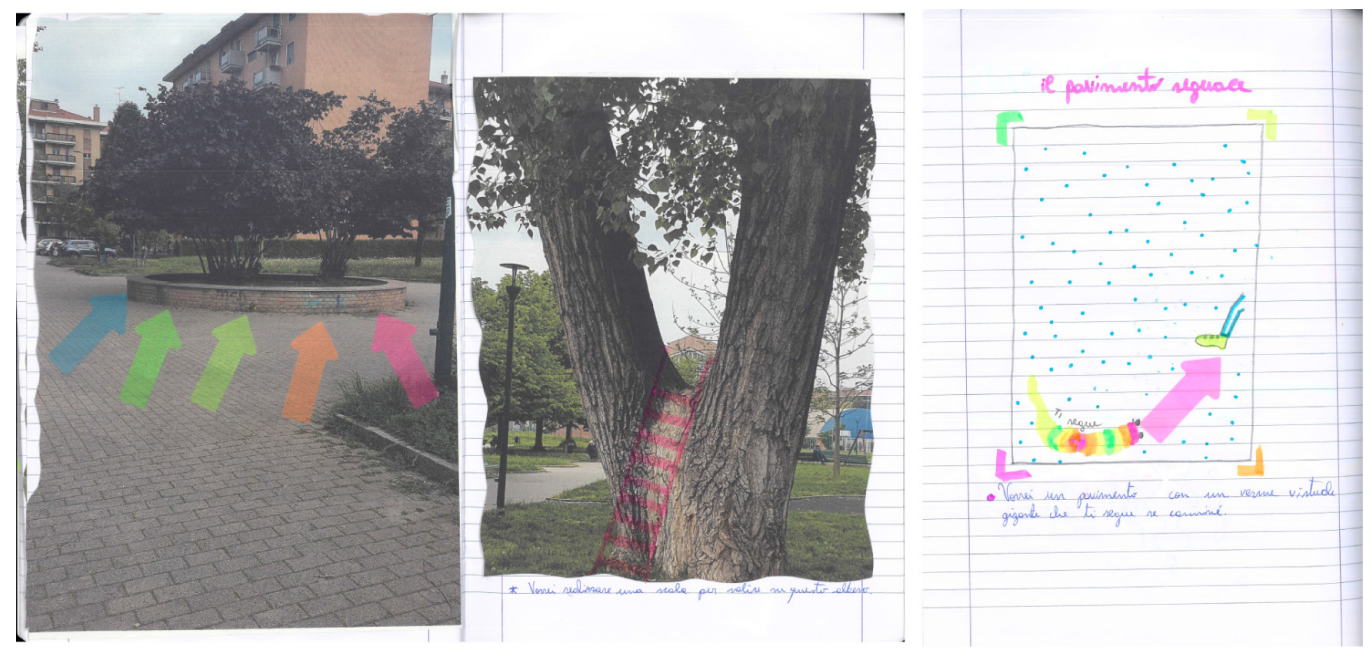

Nel progetto qui in esame sono stati sperimentati diversi percorsi per la costruzione di rappresentazioni individuali e collettive del paesaggio, messi a punto anche grazie all'analisi di buone pratiche documentate, quali quelle qui brevemente richiamate. Un ruolo centrale è stato svolto dalle mappature di percorso, elaborati informali, finalizzati principalmente a raccogliere annotazioni sull'esperienza (sensazioni, riflessioni, ricordi, emozioni...) di attraversamento della periferia urbana. Tra le mappe di percorso prodotte risultano particolarmente significative le mappe mentali che raccontano un tracciato soggettivo ponendo in evidenza la percezione dei giovani cittadini (fig. I). Nonostante la richiesta di costruire una mappa basandosi solo sulla memoria fosse nuova per gli studenti, superato il disorientamento iniziale, i ragazzi (dai 12 ai 18 anni) hanno elaborato rappresentazioni articolate che riflettono la loro attenzione al contesto di vita e al paesaggio urbano e raccontano le molteplici storie racchiuse nella loro esperienza dei luoghi. Gli elaborati presentano i caratteri tipici di questo tipo di mappa [Sobel 1998; Derr et al. 20 I8]. La rappresentazione è selettiva e il disegno degli elementi architettonici e territoriali è semplificato o schematico; compare inoltre una commistione spontanea (e spesso inconsapevole) tra forme di rappresentazione diverse: piante, prospettive e assonometrie intuitive. Non essendoci appoggio al dato metrico né a una base topografica, nei disegni ci sono variazioni di scala significative tra gli elementi del paesaggio, dovute alla distorsione dei rapporti dimensionali filtrati dalla memoria o, in altri casi, legate a una rappresentazione istintivamente simbolica che dà maggior rilievo agli elementi considerati più significativi. Si nota infine l'utilizzo della parola scritta integrata al disegno e l'introduzione di codici iconici e simbolici mutuati dalla rappresentazione cartografica oppure inventati ex novo.

In una fase successiva, alcuni gruppi sono stati invitati a costruire dei diari di bordo come stimolo all'osservazione dei contesti di vita. Nei loro taccuini si trovano annotazioni, disegni, fotografie che pagina dopo pagina restituiscono una riflessione critica sullo spazio urbano e la manifestazione di un desiderio di trasformazione (figg. 2, 3). 
Attraverso queste esperienze gli studenti hanno avuto modo di riflettere sulle caratteristiche del paesaggio a loro familiare, di esprimere una visione soggettiva, di rappresentare i propri ricordi, le proprie percezioni, le proprie opinioni, senza preoccuparsi di costruire una descrizione esaustiva o metricamente corretta, o ancora di seguire regole proiettive nel disegno. Il disegno discontinuo del territorio lascia spazio all'introduzione di segni e annotazioni che completano la narrazione dell'esperienza personale dello spazio che diviene, grazie a queste rappresentazioni, patrimonio collettivo (figg. 4,5).

\section{New media per la narrazione del paesaggio}

Video, digital storytelling e map-storytelling

Le capacità di osservazione e di comunicazione del patrimonio culturale possono trarre grande beneficio dall'uso delle tecnologie [Ott, Pozzi 2008; Ott, Poze 20 I I] che consentono un nuovo modo di raccontare e rappresentare il paesaggio quotidiano. Alle classi è stato proposto di creare narrazioni digitali e di dar voce alle proprie riflessioni usando gli storytelling digitali, i video e gli urban game digitali.

II video, strumento già molto utilizzato in ambito scolastico, in questo contesto è stato proposto per raccontare quegli aspetti del paesaggio che non si esauriscono in un unico punto di vista, ma in una moltitudine di sfumature, dando cosi voce agli abitanti dei luoghi e alle loro storie. Ad esempio, in una classe seconda di una scuola primaria il percorso di lettura del quartiere è stato raccontato per mezzo di video-interviste che i bambini hanno effettuato agli artigiani che lavorano in botteghe e officine affacciate sulla via della loro scuola. Con l'uso di questo strumento i bambini sono riusciti a rappresentare la natura fortemente multiculturale del quartiere in cui abitano e della loro stessa scuola, costruendo un collegamento tra territori e culture. Focalizzarsi su un elemento di patrimonio immateriale ha inoltre consentito di costruire dei ponti con le culture di origine dei bambini. Ne risulta un mosaico di narrazioni sul tema del lavoro, dei materiali, delle tradizioni artigianali, delle forme sociali e dei luoghi del commercio: dai mercati rurali di Haiti, alla bottega storica dei quartieri milanesi, passando per il laboratorio di sartoria gestito da cittadini egiziani (fig. 6). I video

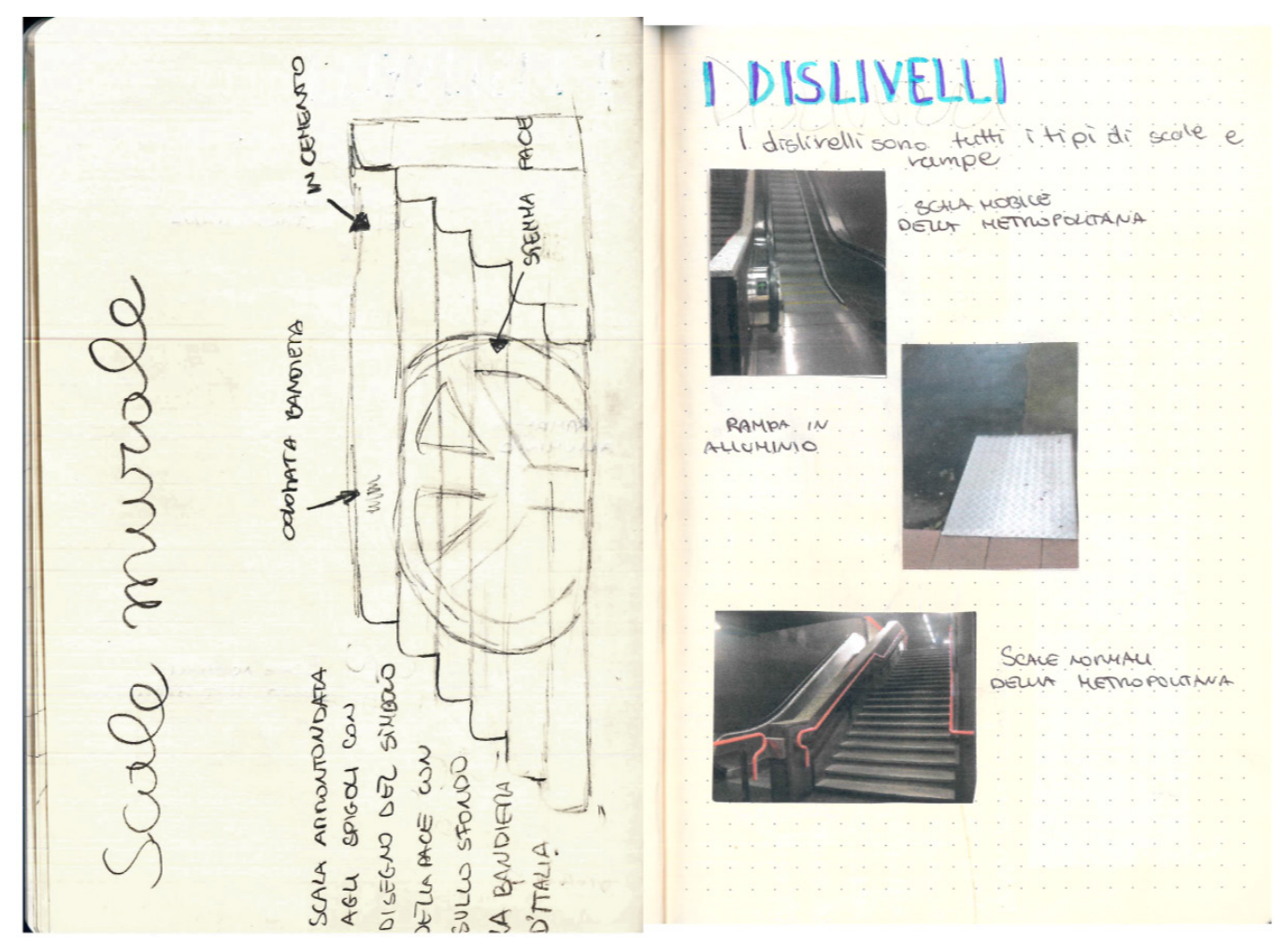


sono stati poi inseriti in una più ampia operazione di mappatura digitale e la via della scuola con le botteghe mappate è stata rappresentata in un plastico costruito dai bambini stessi.

L'utilizzo del video è presente anche all'interno degli storytelling digitali, associato ad una componente testuale. In questo contesto il progetto ScAR ha collaborato con "PoliCultura", un concorso nazionale di storytelling digitale che da anni raccoglie narrazioni provenienti da tutte le regioni italiane. Viene proposto alle scuole di creare racconti multimediali utilizzando lo strumento autore "I00I storia" messo a punto dal laboratorio HocLab del Politecnico di Milano dove, dopo aver definito la struttura narrativa della storia, gli studenti e i docenti possono realizzare e caricare i contenuti: immagini, testi, didascalie, disegni, file audio e video. Questo tipo di attività permette a tutti i ragazzi di partecipare al processo progettuale valorizzando le competenze e le attitudini personali. Le narrazioni multimediali diventano un'occasione per portare al centro dei racconti quei luoghi che invece prima venivano percorsi distrattamente dai ragazzi. Nel caso di una classe terza della scuola secondaria di secondo grado di Isernia, ad esempio, il paesaggio osservato dagli studenti durante il viaggio che devono affrontare per arrivare a scuola viene raccontato attraverso una percezione dinamica dello spazio. La rappresentazione non si riduce quindi alla visione statica di un panorama, ma è legata alla fruizione del territorio durante il movimento sull'autobus. Gli alunni riflettono su come la natura collinare e franosa del proprio territorio rendano difficoltosi i collegamenti pubblici interni causando lunghi tempi di percorrenza che hanno costretto la Regione ad un "atavico isolamento, che molto ha determinato i tratti identitari della popolazione". In altri casi, oltre ai video sono state usate delle sequenze di immagini statiche, come nel caso di una scuola della periferia di Milano dove gli studenti hanno lavorato mediante l'elaborazione digitale delle fotografie. Hanno utilizzato delle viste di palazzi di edilizia popolare del proprio quartiere rivisitandoli digitalmente con delle soluzioni grafiche, sovrapponendo campiture di colore, disegni e riferimenti di opere d'arte, cercando di tradurre in immagine i propri desideri e timori per il futuro dei luoghi che abitano (fig. 7). Questa scuola si trova in un contesto urbano che non presenta apparentemente alcun elemento d'interesse paesaggistico, gli studenti tuttavia hanno saputo trovare un tema caratterizzante il loro quartiere: quello della street art (fig. 8). II progetto ha portato a una visione della periferia come di "un

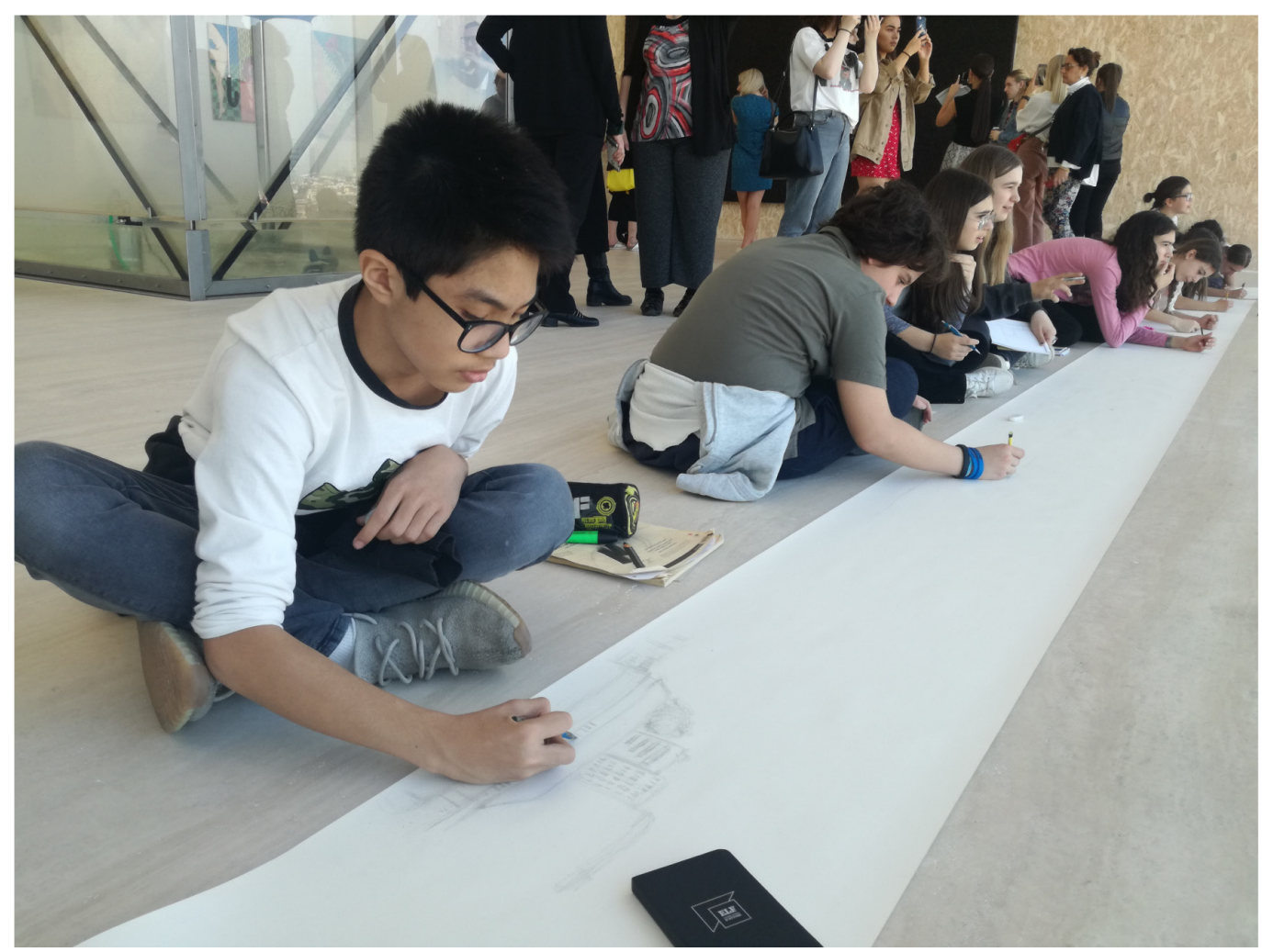


Fig. 5. Studenti della scuola secondaria mostrano le loro mappe mentali dei percorsi casa-scuola.
Fig. 6. I bambini di una classe seconda della sarto egiziano nella via della loro scuola sul tema del lavoro artigianale.

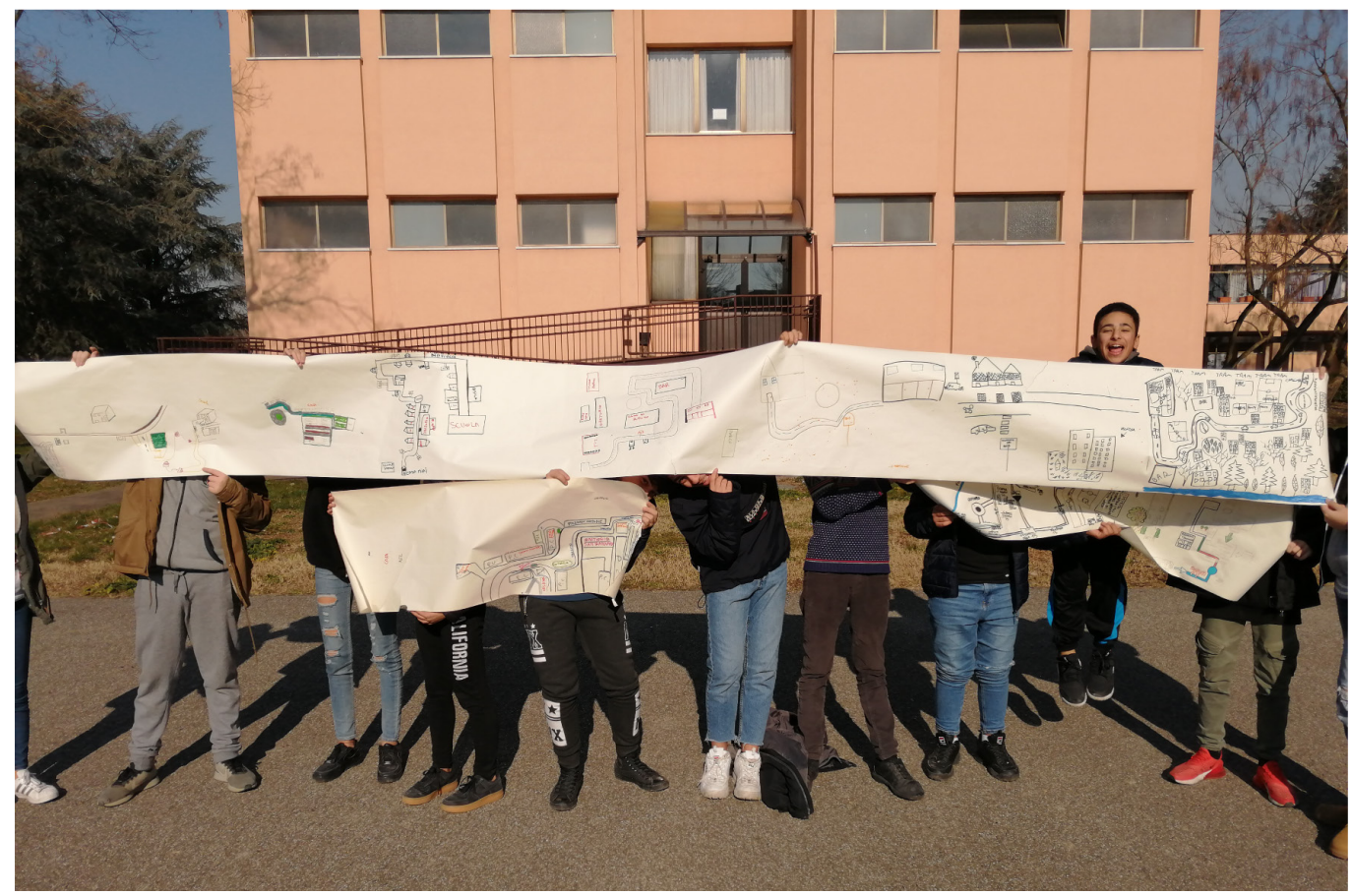

fecondo paesaggio in cui far muovere i bisogni espressivi e le storie degli adolescenti" (relazione conclusiva dell'insegnante), i quali si sono immersi nel quartiere raccogliendo materiali e testimonianze sul territorio, elaborandoli e restituendo un racconto della propria periferia che ne fa emergere gli aspetti meno noti e i valori nascosti.

Una tipologia specifica di storytelling sperimentata con le scuole secondarie e particolarmente adatta a costruire narrazioni relative ai luoghi è lo storytelling basato su mappa (map-storytelling). Per questa attività è stato utilizzato StoryMapJS, un free tool che permette di combinare mappe con testi, foto e video. E stato possibile così dare vita a diverse forme di narrazione, per esempio concentrandosi sul percorso che i ragazzi compiono da casa a scuola e svelando il territorio attraverso punti di interesse individuati sulla mappa e arricchiti con note storiche sull'architettura e il paesaggio, riferimenti a vicende di storia recente e anche storie inventate dagli studenti o riferimenti alla cultura giovanile.

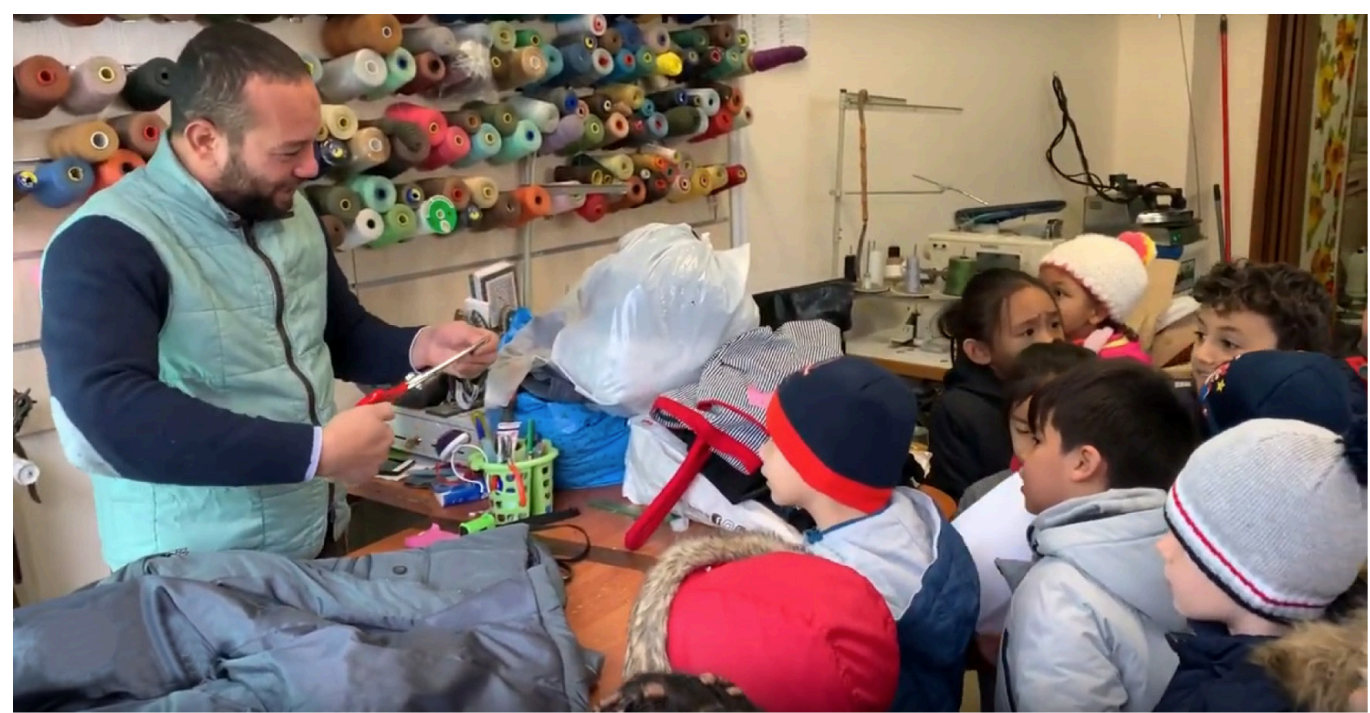


Fig. 7. Elaborazioni digitali su base fotografica realizzate dagli studenti di un istituto professionale che ipotizzano una nuova immagine per nuova immagine per gil

Fig. 8. Uno studente della scuola secondaria impegnato in attività di videomaking per realizzazione di uno storytelling di classe sul tema della street-art nel quartiere del suo istituto. (Credits: ScAR project).
I ragazzi producono con il supporto di strumenti digitali delle rappresentazioni dei propri quartieri che sono inesperte, ma non distratte. Si tratta di produzioni cariche di una sensibilità e di un'attenzione che può pervenire solo da chi conosce il proprio ambiente di vita, come nel caso di uno studente che ha raccontato, attraverso uno storytelling digitale, del paesaggio che vede dal quinto piano di un palazzo di edilizia popolare della periferia milanese. Nonostante abiti da solo tre anni nel quartiere, il ragazzo lo sente familiare e si emoziona alla vista dalla finestra di casa sua, riconoscendo a quel contesto territoriale dei valori che difficilmente un occhio esterno potrebbe individuare.

Da questi esempi emerge che la costruzione di una narrazione multimediale spinge gli studenti a sforzare le proprie capacità di osservazione, spostando l'attenzione verso il paesaggio e consentendo una riflessione sui luoghi, attraverso la loro rappresentazione.
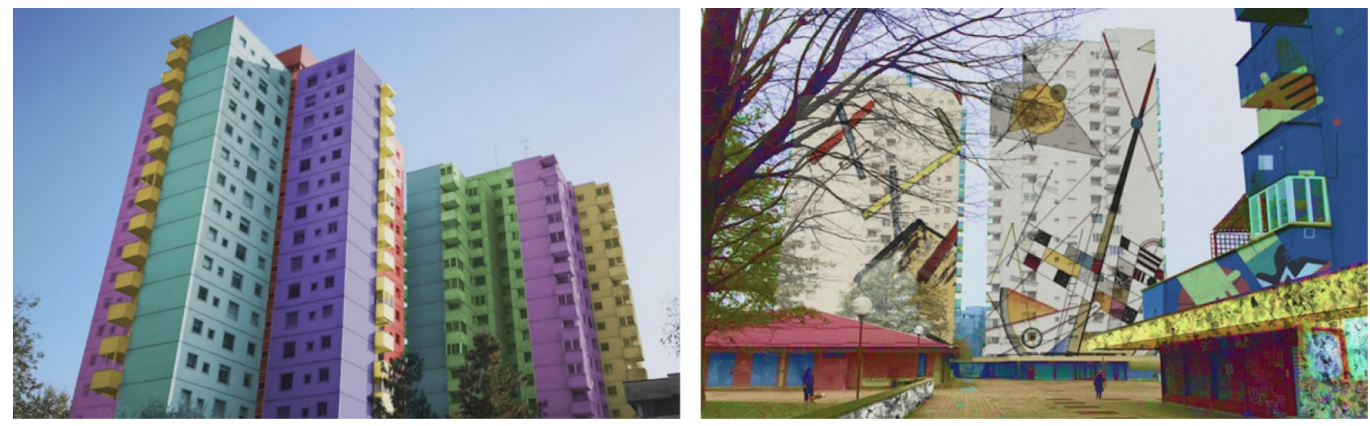

Narrazioni per giocare e scoprire

La narrazione è anche l'elemento centrale della costruzione di un gioco interattivo per dispositivi mobili ideato con gli studenti ( I2- I 3 anni) e basato sulla struttura della caccia al tesoro. I ragazzi hanno individuato il percorso e i punti di interesse che segnano le tappe, raccolto le informazioni sul patrimonio culturale, elaborato i quesiti. II gioco è stato poi sviluppato da esperti esterni e messo a disposizione del pubblico attraverso l'app gratuita GaiaSmart. Ne è risultato un serious game che, seguendo il filo di un racconto, guida l'utente alla scoperta dei quartieri di periferia. In un caso un adolescente immaginario, Ambrogio, accompagna i giovani utenti alla ricerca del loro futuro, cercando nel territorio indizi di quello che vorrà diventare nella sua vita da adulto. In un altro caso è Gerolamo, antica marionetta di uno storico teatro meneghino, a guidare il pubblico alla scoperta di architetture antiche e recenti, corsi d'acqua, elementi di archeologia industriale, istallazioni d'arte e del patrimonio immateriale legato alla tradizione marionettistica dello storico atelier dei Fratelli Colla (fig. 9).

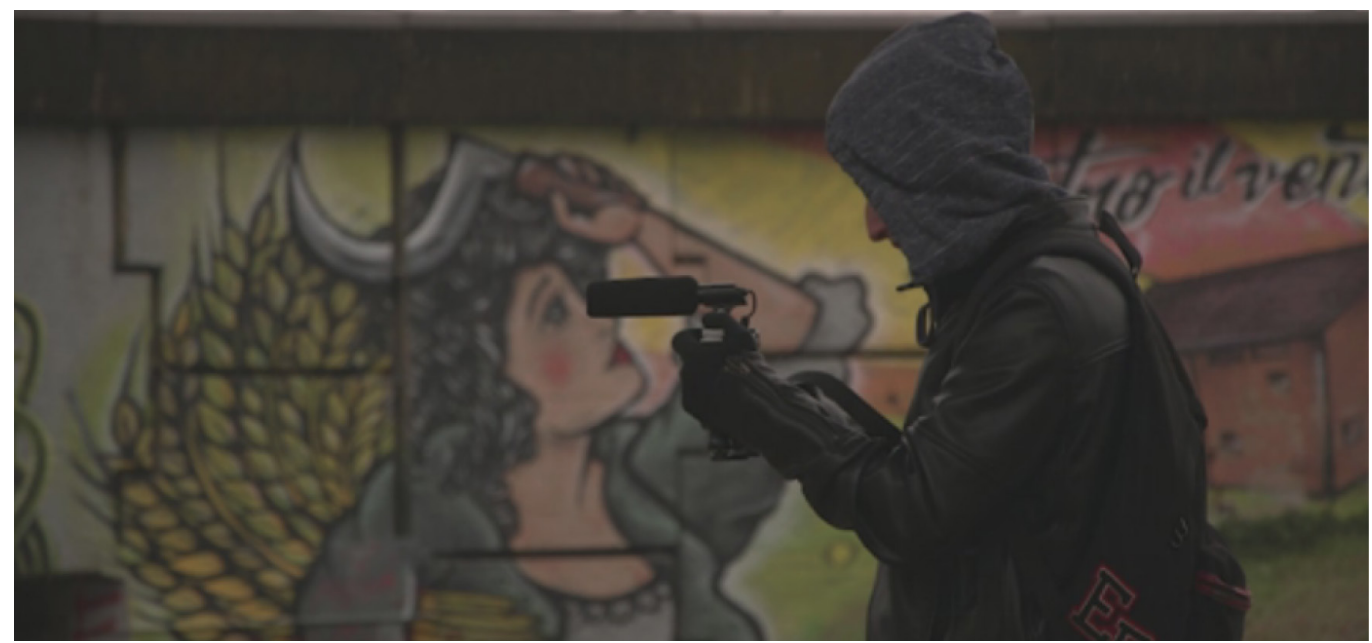




\section{Conclusioni}

Il progetto mostra come sperimentando attività diverse (il diario di bordo, la mappa di percorso, la mappa mentale, la mappa digitale, lo storytelling, il gioco educativo) studenti anche giovani o giovanissimi possono entrare in contatto in modo diretto, esperienziale e intuitivo con modalità di racconto e descrizione del paesaggio e del patrimonio culturale molteplici, avvicinandosi ai linguaggi disciplinari della rappresentazione architettonica e paesaggistica e scoprendo le diverse potenzialità euristiche e comunicative dei metodi e degli strumenti (analogici e digitali) utilizzati.

Le attività qui descritte oltre a raccogliere narrazioni, stimolano l'osservazione attenta del paesaggio quotidiano, consentendo così la costruzione di nuove interpretazioni. Traducendosi poi in rappresentazioni grafiche e scritto-grafiche le diverse letture divengono trasmissibili, consentendo lo scambio e il confronto tra i pari e con soggetti esterni al gruppo (docenti, genitori ma anche amministratori, esperti, decisori).

La raccolta e lo scambio di narrazioni facilita la trasmissione del sapere dalle generazioni anziane a quelle giovani, e al tempo stesso consente lo scambio di punti di vista sui luoghi, in un intreccio di visioni che diviene una riflessione plurale e intergenerazionale sulle trasformazioni avvenute e in atto. Allo stesso modo la narrazione è occasione di incontro tra le molteplici culture che si intrecciano nella città contemporanea e che trovano nella comunità scolastica un'insostituibile prima opportunità di dialogo e di condivisione [Copeland 1998; Coppeland 2006].

L'intero processo diviene infine un'occasione per costruire relazioni tra saperi e discipline: il sapere esperto e quello che emerge dal processo partecipativo, le discipline del team di ricerca (rappresentazione, restauro, urbanistica, pedagogia ecc.) e quelle che studenti e insegnanti mettono in campo (storia, letteratura, geografia ecc). Si costruisce inoltre un ponte tra sapere consolidato e sapere rinnovato attraverso i processi di riscoperta delle memorie dei luoghi e del patrimonio culturale materiale e immateriale nascosto nelle trame del paesaggio della vita quotidiana [I]

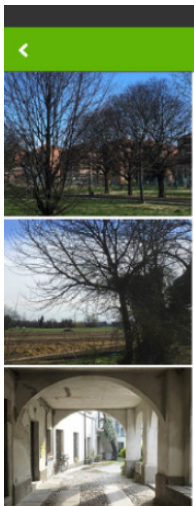

$\mathrm{O} 2 \mathrm{~h}$
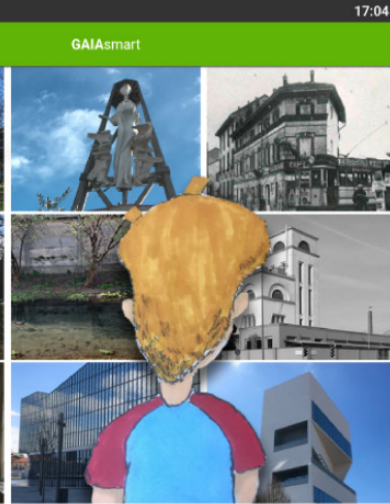

d. Si

VIGENTOUR - CERCA IL TUO «FUTURO» NEL VIGENTINO

Itinerario libero in Milano

Un ragazzino, Ambrogio, esce dalla scuola media Toscanini e deve decider cosa fare da grande.

Una passeggiata nel suo quartiere, il Vigentino, tra passato e presente, lo aiuterà a scoprire i suoi talenti e a intraprendere la strada verso il suo futuro.

Litinerario Vigentour e stato realizzato nelliambito del progetto Scuola Attiva Risorse (SCAR) del Politecnico di Milano, vincitore del Polisocial Award 2017 dedicato alle perfiferie urbane finanziato con i fondi del $5 \times 1000$ IRPEF www.scar,polimi.it

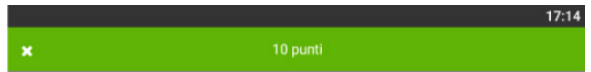

Eccoci arrivati al capolinea del tram 24, dove il grande tram invertiva il senso di marcia per ricominciare il suo percorso verso il centro di Milano. Era il centro dell'antico borgo Vigentino, una località rurale di antica origine, molto bella e semplice. II suo nucleo storico si sviluppò lungo via Ripamonti. In eta napoleonica, dal 1808 al 1816, il Vigentino fu aggregato per la prima volta Milano, recuperando l'autonomia con la costituzione del Regno LombardoVeneto. Nel 1869 il comune di Vigentino venne aggregato a Vaiano Valle e a quello di Quintosole per un insieme di duemila persone, ma $\|$ maggior peso

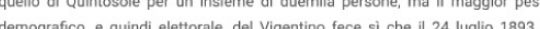
consigitio comuna dopo il governo italiano decretò la mutazione della denominazione comunale. Fu costruito agli inizi del XX il primo complesso residenziale pubblico, lo IACP Ripamonti. Gli abitanti del Vigentino nel 1921 furono addirittura 8211.Nel 1923 Comune di Vigentino venne quindi aggregato insieme ad altre dieci località al Comune di Milano. Oggi il Vigentino è un quartiere di Milano, appartenente al Municipio 5 .

Che forza questi tram che fanno avanti e indietro- come in una garat si potrebbe fare un lavoro del genere, il conducente di tram! Però forse, troppe persone, troppi orari strani... no no, non mi convince! Vieni, proseguiamo!

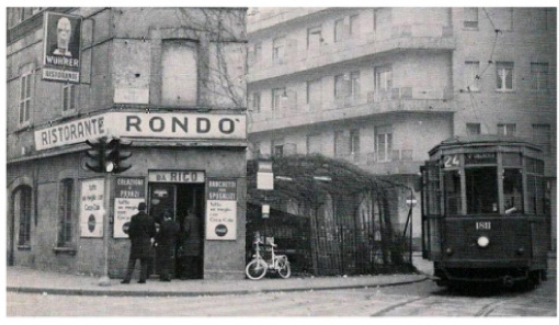

Foto storica: il centro del paese Vigentino dove II tram invertiva il senso di marcia (Foto tratta dal blog "Sei del Vigentino se..." 


\section{Note}

[I] II presente saggio è il risultato di un lavoro comune e i suoi contenuti sono condivisi dalle autrici. All'interno del testo, nello specifico, i paragrafi "Educazione al paesaggio, narrazione e visualità" e "Mappe e disegni per raccontare l'esperienza dello spazio urbano" e "Conclusioni" sono stati redatti da Camilla Casonato, il paragrafo "New media per la narrazione del paesaggio" è stato redatto da Gloria Cossa.

\section{Riferimenti bibliografici}

Bortolotti Adriana, Calidoni Mario, Mascheroni Silvia et al. (2008). Per l'educazione al patrimonio culturale, 22 tesi. Milano: Franco Angeli.

Branchesi Lida (2007). Heritage Education for Europe. Roma: Armando Editore.

Burini Federica (2007). Sistemi cartografici e governance, dalla carta partecipativa ai PPGIS. In Casti Emanuela (ed.). Cartografia e progettazione territoriale. Dalle carte coloniali alle carte di piano. Torino: UTET, pp. I78- 192.

Burini Federica (2013). Metodologie partecipative e processi decisionali inclusivi: dalle iniziative europee alle pratiche italiane. In Burini Federica (ed.). Partecipazione e governance territoriale. Dall'Europa all'Italia. Milano: Franco Angeli, pp. 3 I-53.

Calcagno Maniglio Annalisa (2017). Landscape and education. In Council of Europe (ed.). Landscape dimensions. Reflections and proposals for the implementation of the European Landscape Convention. Strasbourg: Council of Europe Publishing.

CopelandTim (1998). Whose monuments, are they? Whose past is it? The multicultural use of monuments. In Council of Europe (ed.). Cultural heritage and its educational implications: a factor for tolerance, good citizenship and social integration. Strasbourg: Council of Europe Publishing. pp. 39-43.

Copeland Tim (2006). European democratic citizenship, heritage education and identity. Strasbourg, France: Council of Europe Publishing.

Council of Europe (ed.). (1998). Cultural Heritage and its educational implications: a factor for tolerance, good citizenship and social integration: Proceedings. Brussels Seminar 1995. Strasbourg: Council of Europe Publishing.

DeTroyerV. (ed.). (2005). Hereduc. Heritage Education in the classroom. A Practical Manual for Teachers. Antwerpen-Apeldoom: Garant.

Derr Victoria, Chawla Louise, Mintzer Mara (20 I 8). Placemaking with Children and Youth. Participatory Practices for Planning Sustainable Communities. New York: New York Village Press.

IFAD, International Fund for Agricultural Development (2009). Good practices in participatory mapping.

Jenkins, Henry (2009). Confronting the Challenges of Participatory Culture Media Education for the 2 Ist Century. Cambridge, MA, USA: MIT Press.

Luigini Alessandro (ed.). (2019). Proceedings of the Ist International and Interdisciplinary Conference on Digital Environments for Education, Arts and Heritage, EARTH 2018. Cham, Switzerland: Springer.

Ott Michela, Pozzi Francesca (2008). ICT and Cultural Heritage Education: Wich Added Value?. In Lytras D. Miltiadis, Carrol Jhon M., Damiani Ernesto, Tennyson Robert D. (eds.). Emerging Technologies and Information Systems for the Knowledge society. Proceedings of the World Summit on the Knowledge Society. WSKS 2008, Athens Greece, September 24-26 2008. Berlin, Heidelberg: Springer.

Ott Michela, Pozzi Francesca (20 I I).Towards a new era for Cultural Heritage Education. Discussing the role of ICT. Computers in Human Behavior, 27 (4), pp. I365-137I.

Sobel David (1998). Mapmaking with children. Sense of place education for the elementary years. Portsmouth, NH, USA: Heinemann. Van Lakerveld Jaap, Gussen Ingrid (eds.). (20II). Aqueduct. Acquiring Key Competences through Heritage Education. Bilzen, Belgium: Lies Kerkhofs, Landcommanderij Alden Biesen.

Waterton Emma, Watson Steve (eds.). (2010). Culture, Heritage and representation. Perspectives on Visuality and the past. Farnham: Ashgate.

\section{Websites}

Educational sector of the Conseils d'Architecture, d'Urbanisme et de l'Environnement <https://www.fncaue.com/portail-pedagogique/>.

\section{Autori}

Camilla Casonato, Politecnico di Milano, camilla.casonato@polimi.it

Gloria Cossa, Politecnico di Milano, gloria.cossa@mail.polimi.it

Per citare questo capitolo: Casonato Camilla, Cossa Gloria (2020). Landscape stories. Visual storytelling on the everyday landscape. In Arena A. Arena M., Brandolino R.G., Colistra D., Ginex G., Mediati D., Nucifora S., Raffa P. (a cura di). Connettere. Un disegno per annodare e tessere. Atti del $42^{\circ}$ Convegno Internazionale dei Docenti delle Discipline della Rappresentazione/Connecting. Drawing for weaving relationships. Proceedings of the 42 th International Conference of Representation Disciplines Teachers. Milano: FrancoAngeli, pp. 3025-3042. 


\title{
Landscape Stories. Visual Storytelling on the Everyday Landscape
}

\author{
Camilla Casonato \\ Gloria Cossa
}

Abstract

Narration is central in the knowledge building process about the landscape and its cultural value. The enhancement of the everyday landscape, in particular, requires a shared interpretative process based on intercultural and intergenerational dialogue. The essay refers to a field research experience involving primary and secondary school students in a process of discovery, interpretation and communication of the material and immaterial cultural heritage enclosed in the landscape of the urban suburbs. The paper presents different forms of narrative used during the project, in particular visual storytelling and new media narratives (traditional and digital route maps, mental maps, logbooks, videos, digital storytelling, serious games). Through the project, young students experienced multiple ways to describe the landscape and the cultural heritage. In this way children and teenagers have approached the disciplinary languages of architectural and landscape representation and discovered the different heuristic and communicative potentialities of different methods and tools (analog and digital).

Keywords

narration, ICT, new media, landscape education, participatory, representation.

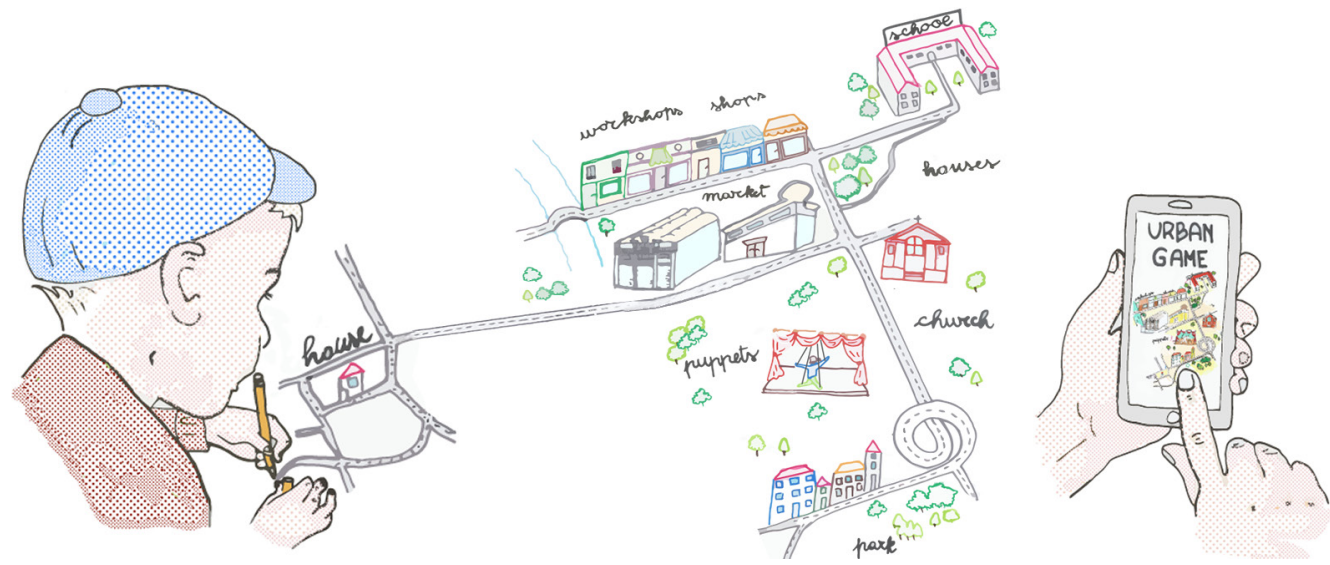




\section{Landscape education, narration and visuality}

Narration is central in the knowledge building process about the landscape and its cultural values. Finding strategies, tools and methodologies to build a shared narrative of places is essential in particular in the paths that address the landscape of everyday life, whose values can only be highlighted through a collective process of interpretation [Bortolotti et al. 2008; Branchesi 2007; Calcagno Maniglio 20 I7; Derr et al. 20 I8].

This essay refers to the experience of an interdisciplinary research team of Politecnico di Milano engaged in a two-year process of development and experimentation of landscape education methodologies and tools in the schools of the urban suburbs. The 'Scuola Attiva Risorse (SCAR)' project was funded in 2018 under the Polisocial programme and involved over six hundred students from primary to secondary school in a two years process of discovery, interpretation and communication of the tangible and intangible cultural heritage hidden in the everyday landscape. Within the project, traditional activities (although not always usual for schools) and activities involving the use of technology were combined. The itineraries in the neighbourhoods and the collection of memories were accompanied by urban sketching, mapping, models building, urban design. The introduction of ICTs in the process allowed the development of specific communication products, such as digital maps, multimedia tourist guides, serious games. In the light of this path we propose some considerations on the experience, focusing on the different forms of narrative that have supported the project, especially visual storytelling and activities involving the new media.

Fig. I. Mental maps of the route from home to school made by the students of a secondary school. Credits: ScAR project.
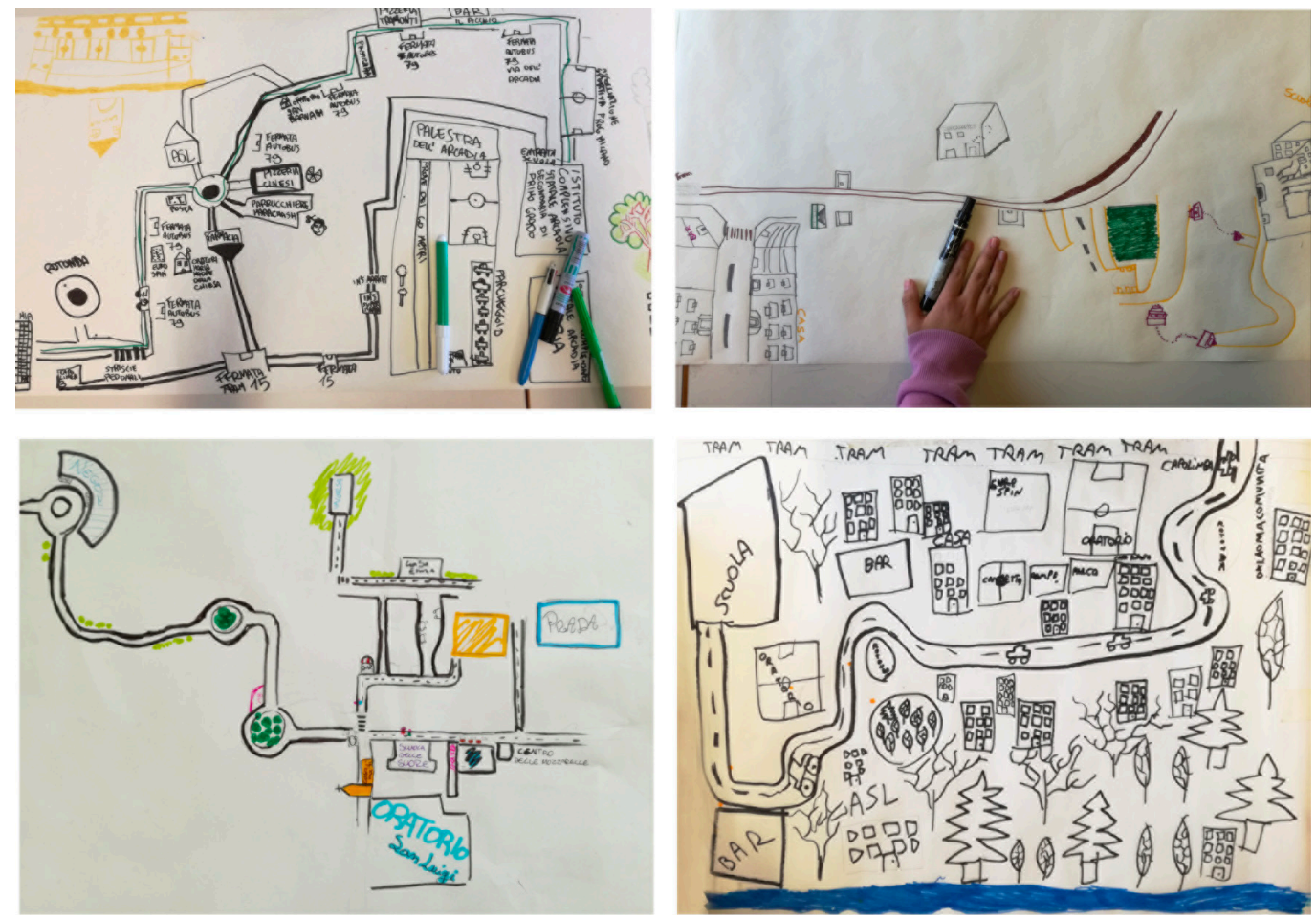


\section{Maps and drawings telling the experience of the urban space}

Participatory territorial representation is traditionally used to share people's experience of the places. This practice is largely linked to educational processes: interesting examples in this sense are present in the Anglo-Saxon [Derr 20 I8; Sobel 1998] and in particular French contexts, as demonstrated by the systematic educational action carried out by the Conseils d'Architecture, d'Urbanisme et de l'Environnement. Another interesting case study are the participatory knowledge-building processes typical of community museums and development cooperation programmes [Burini 2007; Burini 20I3; IFAD 2009].

Fig. 2. Images from a logbook of a 12 years old student who tells about the desire to inhabit a tree by simply drawing a staircase and imagine a floor with a "virtual worm" following her Credits: ScAR project.
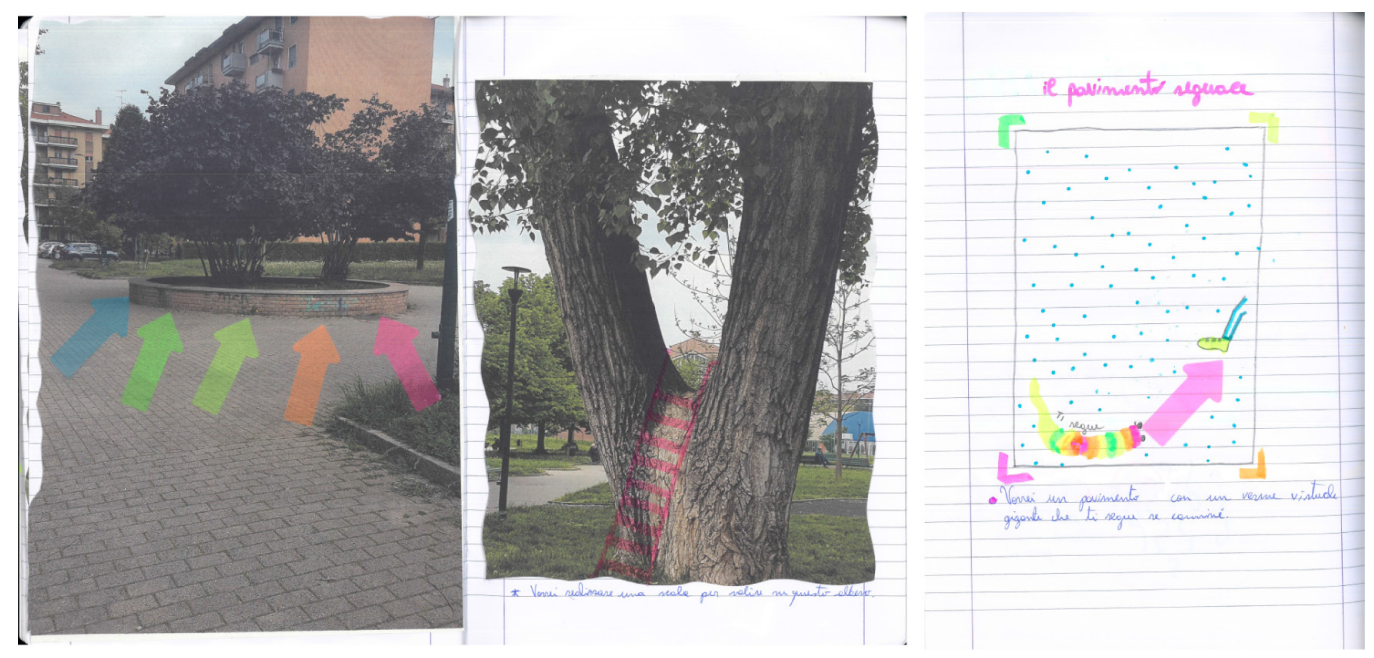

During the ScAR project, students participated in the construction of individual and collective landscape representations. A central role has been played by route maps, which have been elaborated informally, mainly aimed at collecting students' impressions and feelings on their routes through the urban periphery (sensations, reflections, memories, emotions etc.). In this context particularly significant are mental maps that tell a subjective outline highlighting the perception of young citizens (fig. I). Although drawing a map based only on one's own memory was a new experience for the students, after overcoming the initial perplexity, the children ( 12 to 18 years old) developed articulated representations that reflect their attention to the places of everyday life and tell many personal and collective stories. The students' works have the typical characters of this type of map [Sobel 1998; Derr et al. 20 I8]: the representation is selective, and the drawing of the buildings and the landscape is simplified or schematic. There is also a spontaneous (and often unconscious) mixture of different forms of representation: plans, perspectives and parallel projections. The students did not use topographic maps as a basis for their drawings therefore there are significant scale variations among the landscape elements, due to the distortion of the dimensions of the objects and of distances between them in their memory. In other cases, these alterations are linked to an instinctively symbolic representation that gives more prominence to the elements considered more significant. In the maps there are also texts and iconic and symbolic codes borrowed from official cartography or invented. Later on, some groups were invited to create logbooks as a stimulus for the observation of landscape. In their notebooks there are notes, drawings and photographs that page after page give a critical reflection on urban space and its transformations (figs. 2, 3).

Through these experience students had the opportunity to think about the landscape in which they live, moreover they could express a subjective vision and represent their me- 
mories, perceptions, opinions, without worrying about producing an exhaustive description or a metrically correct map, or even to follow projective rules in drawing. A discontinuous drawing of the territory, more than an accurate and realistic depiction, actually leaves room for the introduction of signs and annotations that complete the narration of the personal experience of the space that these representations allow to share (figs. 4,5$)$.

\section{New media for landscape narration}

Video, digital storytelling e map-storytelling

The ability to observe and communicate cultural heritage may greatly benefit by using modern technology [Ott, Pozzi 2008; Ott, Pozzi 20I I], as this allows new way to narrate and represent our everyday landscape. The classes therefore were proposed to create digital narratives and give voice to their reflections using digital storytelling, video and digital urban games.

The video is a tool already known and largely used at school. In this context it has been proposed as a medium to tell those aspects of the landscape that do not end in a single point of view, but in a multitude of shades of a view, giving voice to the inhabitants of the places and their stories. As an example, the children of a second class of a primary school represented their reading path of the neighborhood through video-interviews to the artisans working in laboratories and workshops overlooking the street of their school. With the use of their videos, the children were able to represent the strongly multicultural aspects of their neighborhood and school, and to build a connection between territories and cultures. Focusing on an element of intangible heritage has also made it possible to build bridges with the children's cultures of origin. The result was a mosaic of narratives related to work, materials, traditional handcrafts, social forms, shops and markets: from the rural markets of Haiti to the historical workshop in the Milanese neighborhoods, passing through the tailoring workshop run by Egyptian citizens (fig. 6). The videos were then included in a wider digital mapping

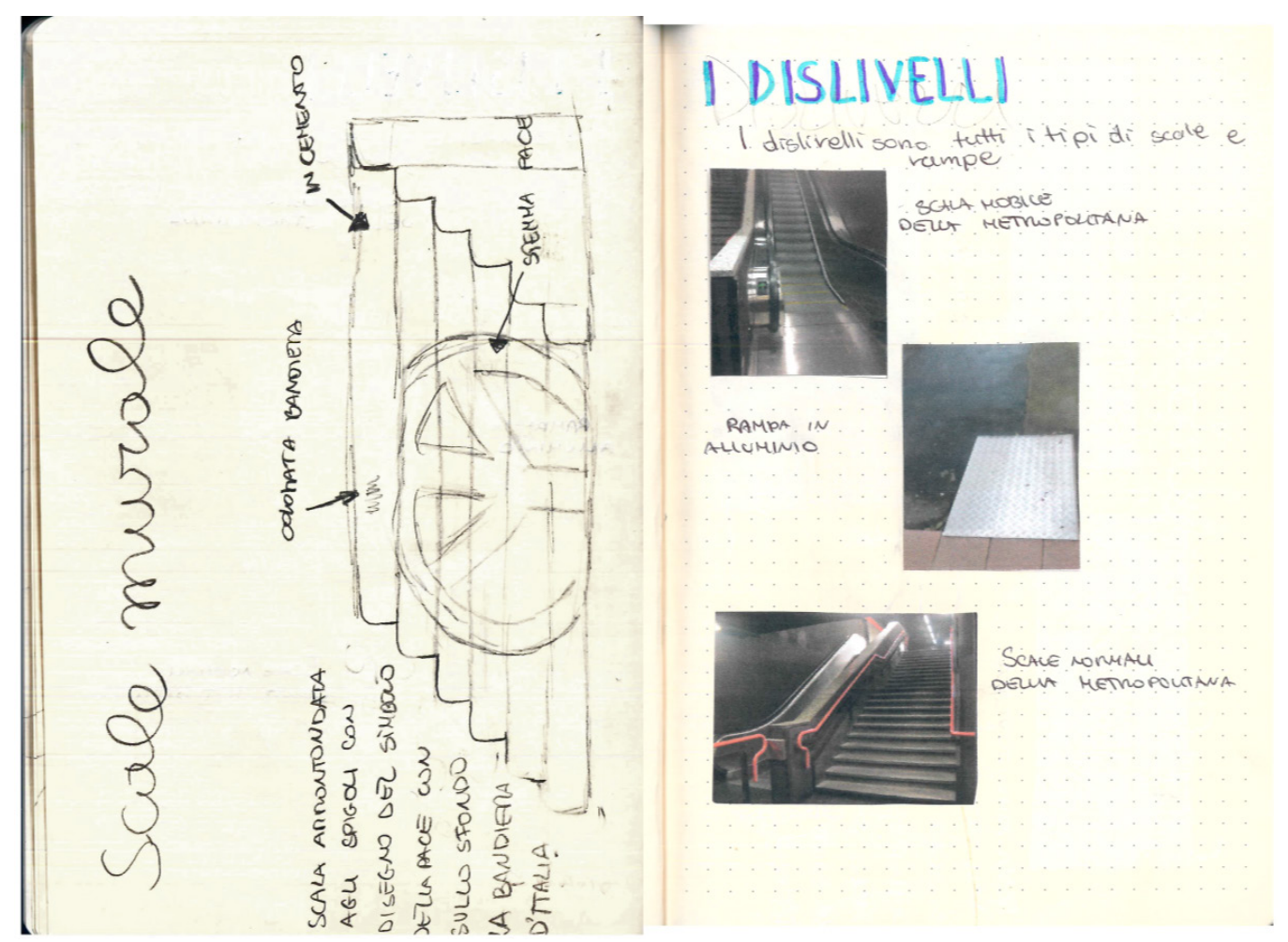


operation and the school street with the mapped shops was represented in a model built by the children themselves.

The use of videos is also present in the digital storytelling, assembled with textual elements. In this context the ScAR project worked in cooperation with "PoliCultura", a national contest of digital Storytelling that has been collecting narrations coming from all over Italy for years. It is proposed to schools to create multimedia stories using the author tool "I00 I storia" developed by the HocLab laboratory of Politecnico di Milano where, after defining the narrative structure of the story, students and teachers can create and upload the contents: images, texts, captions, drawings, audio and video files. This activity allows the students to participate in the design process, enhancing their personal skills and attitudes.

Multimedia narrations become an opportunity to appreciate places that were only distractedly noticed by the students in the past, while those same places have now become the core of their stories. In the case of a third-grade secondary school class in Isernia, for example, the landscape observed by the students during their journey to school is told through a dynamic perception of space. The representation is therefore not reduced to the static vision of a landscape but is linked to the use of the territory during the movement on the bus. The pupils reflect on how the hilly and landslide nature of their territory makes internal public transport difficult, causing long travel times that have forced the Region to "atavistic isolation, which has greatly determined the identity traits of the population". In other cases the students used a series of static images, like in a school on the outskirts of Milan where the students worked through the digital processing of photographs. They used views of social housing buildings in their neighborhood, digitally revisiting them with graphic solutions, by overlapping color crosshatch, drawings and artworks references, trying to translate into images their wishes and fears for the future of their places (fig. 7). The area where this school is located is an urban context without any element of landscape interest, however, the students were able to find a topic characterizing their neighborhood: the street art (fig. 8). The project led to a vision of the suburbs as "a fruitful landscape in which the expressive needs and stories of adolescents can move" (teacher's final report), who

Fig. 4. Secondary school students sketching the landscape they observe from the windows of the eighth floor of the Prada Foundation towe in Milan. Credits: ScAR project.

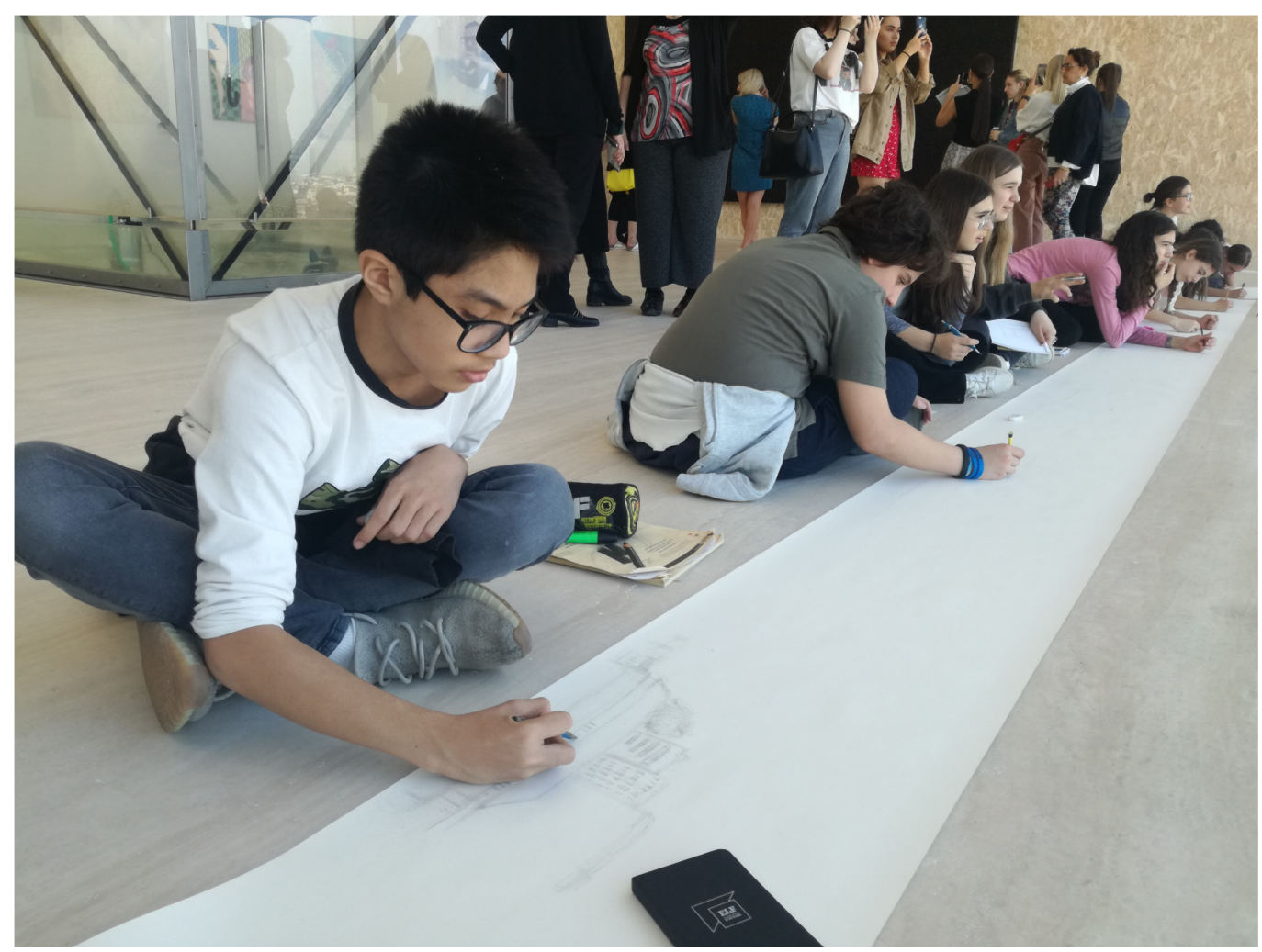


Fig. 5. Secondary school students showing their mental maps of the neighborhoods. Credits: ScAR project.

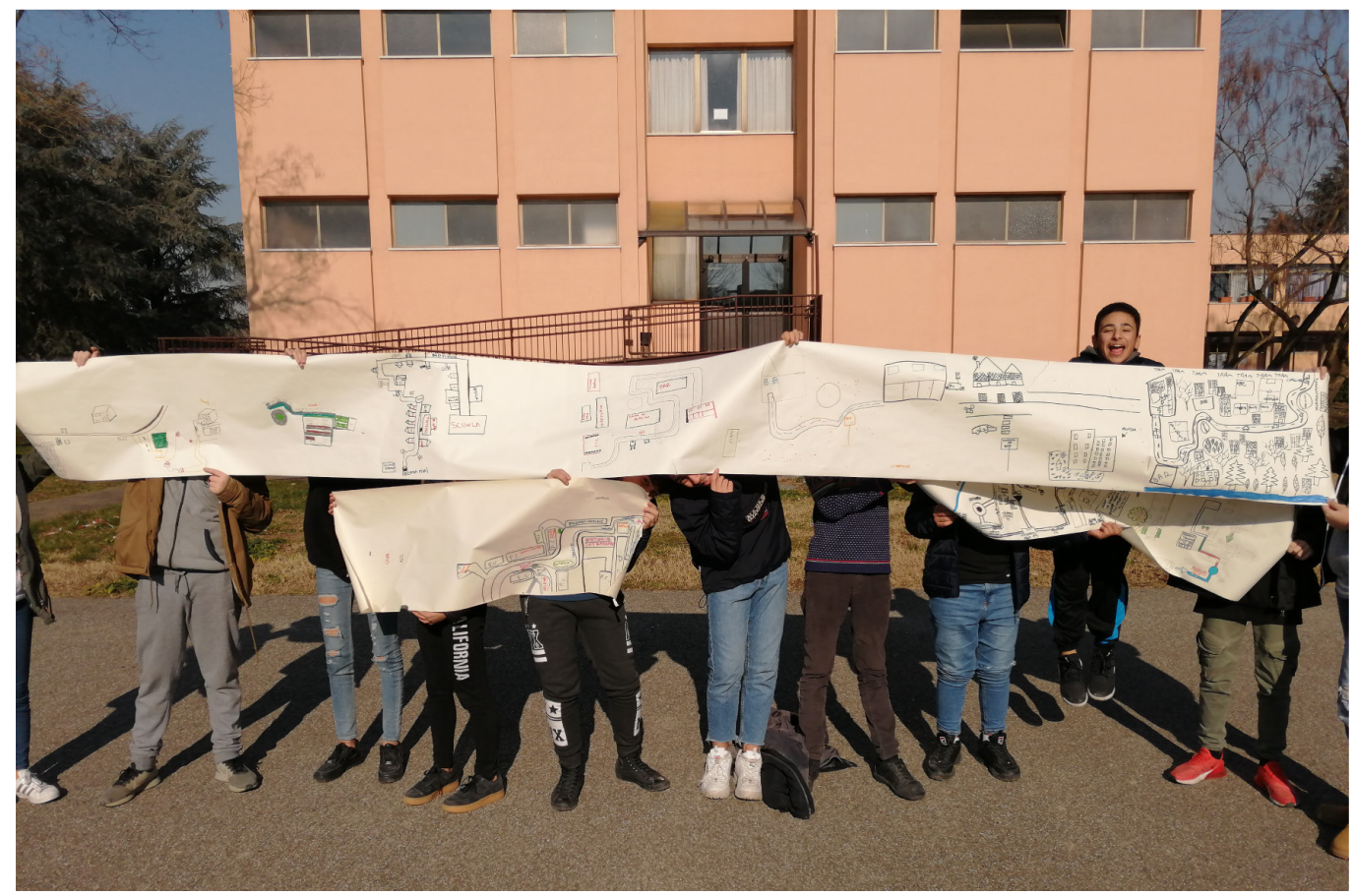

immersed themselves in the neighborhood collecting materials and testimonies about the area, elaborating them and giving back a story of their own suburbs that brings out the less known aspects and hidden values.

A specific type of storytelling experimented with secondary schools, particularly fit to build narrations related to places, is the map-storytelling. The free tool used for this purpose is StoryMapJS, which allows to combine maps and text, photos and videos. In this way it was possible to give life to different forms of storytelling, for example focusing on the path that children take from home to school and revealing the territory through points of interest identified on the map and enriched with historical notes on architecture and landscape, references to recent history and also stories invented by students or references to youth culture.

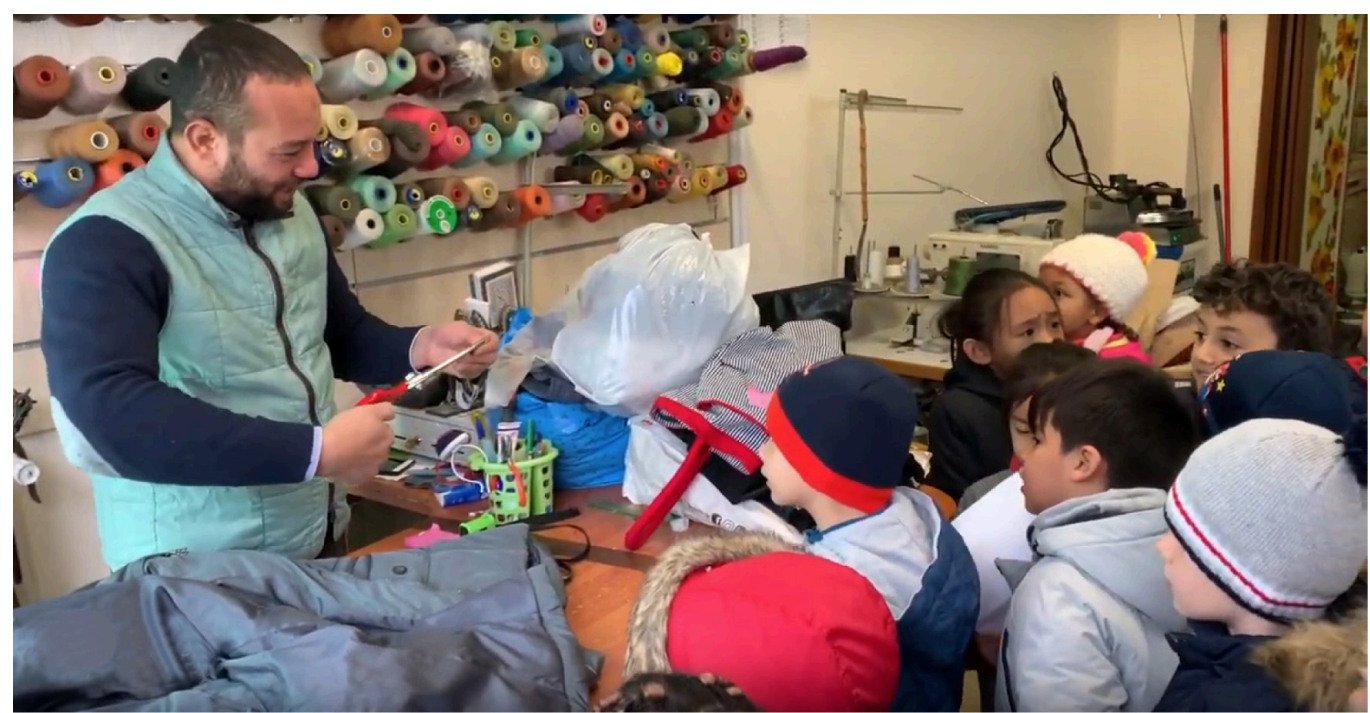

Fig. 6. The children of a primary school in the suburbs of Milan interview the Egyptian the way to their school. Credits: ScAR project. 
The students produce with the support of digital tools, representations of their neighborhoods that are inexperienced but not distracted. These productions are very emotional and attentive, just because the authors know their living environment, as it happened when a student reported, through a digital storytelling, the landscape he sees from the fifth floor of a social housing building on the outskirts of Milan. In spite he has lived there for three years only, he feels a great familiarity and emotion from the view, because he acknowledges to that territory values that couldn't be identified by an outsider.

From the above examples we understand that a multimedia narration leads the students to strain their own observation skills, moving the focus towards the landscape and allowing thoughts on the places through their representation.

Fig. 7. Images digitally processed by the pupils of a secondary school class based in the Gratosoglio district, in the southern suburbs of Milan, with ideas on how to improve the to improve the buildings in which the buildings in which they live. project.
Fig. 8. A student working on the filming for the creation of the digital storytelling on the theme of graffiti in the Gratosoglio district (Milan). Credits: ScAR project.
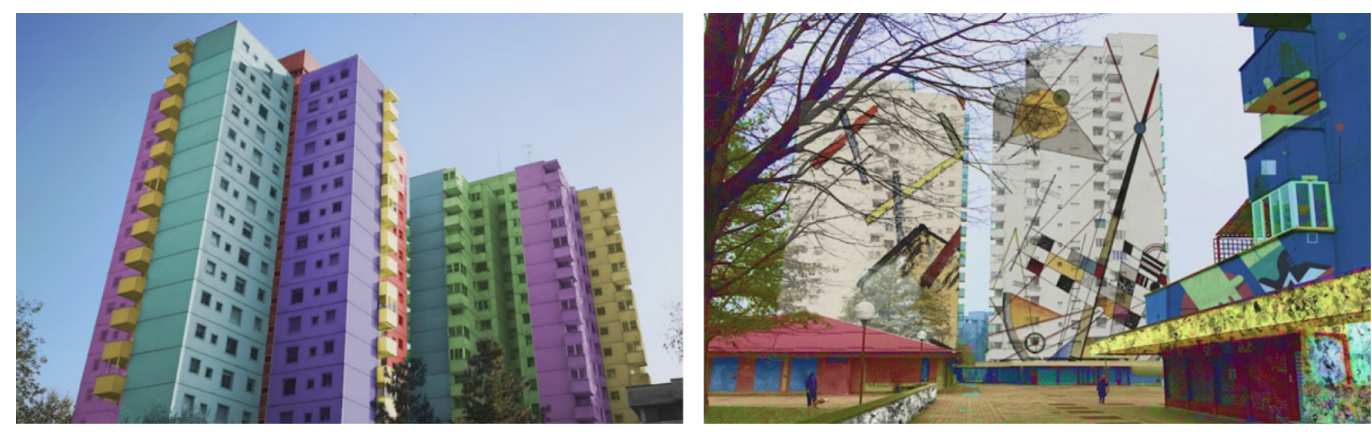

Narrations to play and discover

Narration is also the heart of an interactive mobile game designed in collaboration with students ( $12-13$ years old) based on the structure of the treasure hunt. The pupils identified the route and the points of interest that mark the stages, collected information about the cultural heritage, processed the questions. The game was then developed by experts and made available to the public through a free app named GaiaSmart. The result is a serious game that, following the thread of a story, guides the user to discover the suburbs. In one case an imaginary teenager, Ambrogio, accompanies the player in search of his future, guiding him through the territory in search of clues that will make him think about what he will want to become in his adult life. In another case it is Gerolamo, an ancient puppet from a historical theatre in Milan, who guides the public in the discovery of ancient and recent buildings, waterways, industrial archaeology, art installations and the intangible heritage, such as the puppets tradition of the historical atelier of the Colla Brothers (fig. 9).

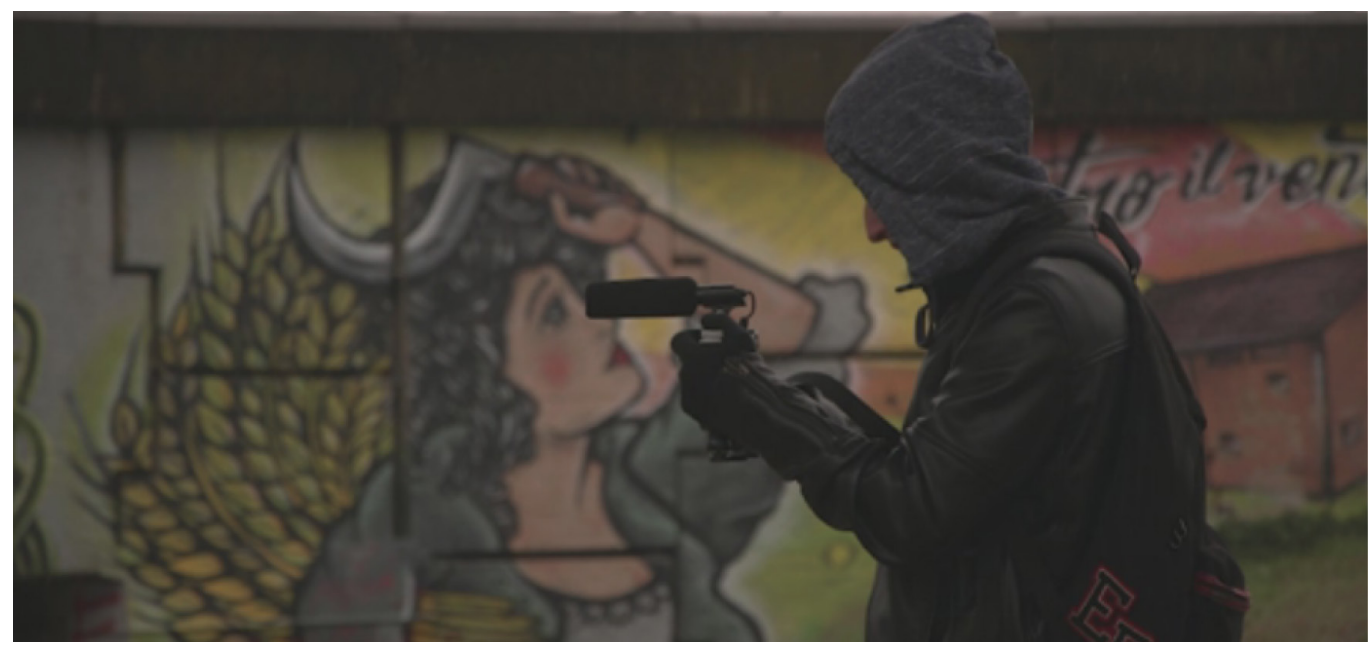




\section{Conclusions}

The project shows how experimenting with different activities (logbook, route map, mental map, digital map, storytelling, educational game ...) students, even young or very young, can get in touch in a direct, experiential and intuitive way with multiple ways of telling and describing the landscape and cultural heritage. In this way they can approach the language of architectural and landscape representation and discover the different heuristic and communicative potential of the used methods and tools (analogic and digital).

The activities described here allow to collect narratives and stimulate the careful observation of the everyday landscape, encouraging the construction of new analyses. Then translated into textual and graphic representations the different readings become transmissible, allowing the sharing of contents among peers and with other participants and stakeholders (teachers, parents but also administrators, experts, decision makers). Therefore, the collection and exchange of narratives allows and stimulate the exchange of points of view on the places, at the same time it facilitates the transmission of knowledge from the older generations to the younger ones. Thus, an interweaving of visions is created that becomes a plural and intergenerational consideration on the transformations that have occurred in the past and which are taking place. In the same way the narrative is an opportunity to relate the many different cultures that intertwine in the contemporary city and that find in the school community an irreplaceable first opportunity for dialogue and sharing [Copeland 1998; Copeland 2006].

Finally, the whole process constitutes an opportunity to twine links between different types of knowledge and disciplines. As a matter of fact, the process creates a synergy between the knowledge of experts and the new information and opinions emerging from the participatory process. At the same time, it combines the disciplines of the research team (representation, restoration, urban planning, pedagogy...) and the disciplines that students and teachers deal with (history, literature, geography etc.). A bridge is also built between consolidated knowledge and renewed knowledge through the rediscovery of memories of places and through the knowledge of the material and immaterial cultural heritage hidden in the plots of the landscape of everyday life [I].

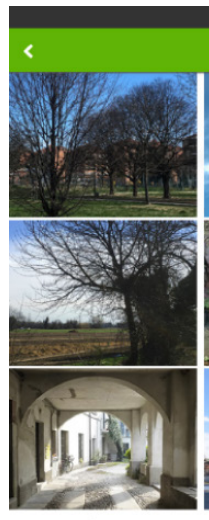

$\mathrm{O} 2 \mathrm{~h}$
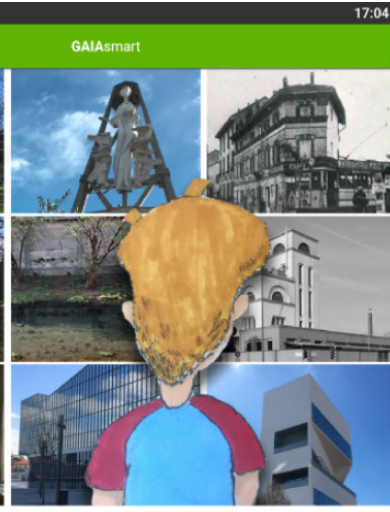

(๓ $5 \mathrm{Km}$

d. Si

VIGENTOUR - CERCA IL TUO «FUTURO» NEL VIGENTINO

Itinerario libero in Milano

Un ragazzino, Ambrogio, esce dalla scuola media Toscanini e deve decidere cosa fare da grande.

Una passeggiata nel suo quartiere, il Vigentino, tra passato e presente, lo aiuterà a scoprire i suoi talenti $\mathrm{e}$ a intraprendere la strada verso il suo futuro.

Litinerario Vigentour è stato realizzato nell'ambito del progetto Scuola Attiva Risorse (SCAR) del Politecnico di Milano, vincitore del Pollisocial Award 2017 dedicato alle periferie urbane e finanziato con i fondi del $5 \times 1000$ IRPEF. www.scar.polimi.j.

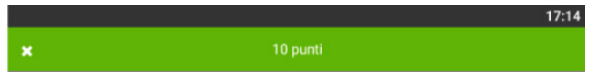

Eccoci arrivati al capolinea del tram 24, dove il grande tram invertiva il senso di marcia per ricominciare il suo percorso verso il centro di Milano. Era il centro dell'antico borgo Vigentino, una località rurale di antica origine, molto bella e semplice. II suo nucleo storico si sviluppò lungo via Ripamonti. In etä napoleonica, dal 1808 al 1816, il Vigentino fu aggregato per la prima volta a Milano, recuperando l'autonomia con la costituzione del Regno LombardoVeneto. Nel 1869 il comune di Vigentino venne aggregato a Vaiano Valle e a quello di Quintosole per un insieme di duemila persone, ma $\|$ maggior peso qences demarco 1893 consiglio comunale delbero to spostamento del municipio, tanto che un mese dopo il governo italiano decretò la mutazione della denominazione comunale Fu costruito agli inizi del XX il primo complesso residenziale pubblico, lo IACP Ripamonti. Gli abitanti del Vigentino nel 1921 furono addirittura 8211. Nel 1923 i Comune di Vigentino venne quindi aggregato insieme ad altre dieci località al Comune di Milano. Oggi il Vigentino è un quartiere di Milano, appartenente al Municipio 5 .

Che forza quest tam che fann avanti e indietro- come in una gat sis potrebbe fare un lavoro del genere, il conducente di tram! Però forse, troppe persone, troppi orari strani... no no, non mi convince! Vieni, proseguiamo!

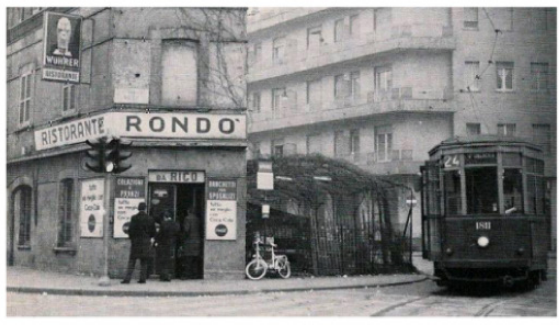

Foto storica: il centro del paese Vigentino dove il tram invertiva il senso di marcia (Foto tratta dal blog "Sei del Vigentino se..." 


\section{Notes}

[I] This essay is the result of a common work and its contents are shared by the authors. Within the text, specifically, the paragraphs Landscape education, narration and visuality, Maps and drawings to tell the experience of urban space and Conclusions have been written by Camilla Casonato, the paragraph New media for landscape narration has been written by Gloria Cossa.

\section{References}

Bortolotti Adriana, Calidoni Mario, Mascheroni Silvia et al. (2008). Per l'educazione al patrimonio culturale, 22 tesi. Milano: Franco Angeli.

Branchesi Lida (2007). Heritage Education for Europe. Roma: Armando Editore.

Burini Federica (2007). Sistemi cartografici e governance, dalla carta partecipativa ai PPGIS. In Casti Emanuela (ed.). Cartografid e progettazione territoriale. Dalle carte coloniali alle carte di piano. Torino: UTET, pp. I78- 192

Burini Federica (2013). Metodologie partecipative e processi decisionali inclusivi: dalle iniziative europee alle pratiche italiane In Burini Federica (ed.). Partecipazione e governance territoriale. Dall'Europa all'Italia. Milano: Franco Angeli, pp. 31-53.

Calcagno Maniglio Annalisa (20 17). Landscape and education. In Council of Europe (ed.). Landscape dimensions. Reflections and proposals for the implementation of the European Landscape Convention. Strasbourg: Council of Europe Publishing.

Copeland Tim (1998). Whose monuments, are they? Whose past is it? The multicultural use of monuments. In Council of Europe (ed.). Cultural heritage and its educational implications: a factor for tolerance, good citizenship and social integration. Strasbourg: Council of Europe Publishing. pp. 39-43.

Copeland Tim (2006). European democratic citizenship, heritage education and identity. Strasbourg, France: Council of Europe Publishing.

Council of Europe (ed.). (1998). Cultural Heritage and its educational implications: a factor for tolerance, good citizenship and social integration: Proceedings. Brussels Seminar 1995. Strasbourg: Council of Europe Publishing.

DeTroyerV. (ed.). (2005). Hereduc. Heritage Education in the classroom. A Practical Manual for Teachers. Antwerpen-Apeldoom: Garant.

Derr Victoria, Chawla Louise, Mintzer Mara (2018). Placemaking with Children and Youth. Participatory Practices for Planning Sustainable Communities. New York: New York Village Press.

IFAD, International Fund for Agricultural Development (2009). Good practices in participatory mapping.

Jenkins, Henry (2009). Confronting the Challenges of Participatory Culture Media Education for the 2 Ist Century. Cambridge, MA USA: MIT Press.

Luigini Alessandro (ed.). (2019). Proceedings of the Ist International and Interdisciplinary Conference on Digital Environments for Education, Arts and Heritage, EARTH 2018. Cham, Switzerland: Springer.

Ott Michela, Pozzi Francesca (2008). ICT and Cultural Heritage Education: Wich Added Value?. In Lytras D. Miltiadis, Carrol Jhon M., Damiani Ernesto, Tennyson Robert D. (eds.). Emerging Technologies and Information Systems for the Knowledge society. Proceedings of the World Summit on the Knowledge Society. WSKS 2008, Athens Greece, September 24-26 2008. Berlin, Heidelberg: Springer.

Ott Michela, Pozzi Francesca (20 I I).Towards a new era for Cultural Heritage Education. Discussing the role of ICT. Computers in Human Behavior, 27 (4), pp. $1365-1371$.

Sobel David (1998). Mapmaking with children. Sense of place education for the elementary years. Portsmouth, NH, USA: Heinemann.

Van Lakerveld Jaap, Gussen Ingrid (eds.). (20 I I). Aqueduct. Acquiring Key Competences through Heritage Education. Bilzen, Belgium: Lies Kerkhofs, Landcommanderij Alden Biesen.

Waterton Emma, Watson Steve (eds.). (2010). Culture, Heritage and representation. Perspectives on Visuality and the past. Farnham: Ashgate.

\section{Websites}

Educational sector of the Conseils d'Architecture, d'Urbanisme et de l'Environnement <https://www.fncaue.com/portail-pedagogique/>.

\footnotetext{
Authors

Camilla Casonato, Politecnico di Milano, camilla.casonato@polimi.it

Gloria Cossa, Politecnico di Milano, gloria.cossa@mail.polimi.it
}

To cite this chapter. Casonato Camilla, Cossa Gloria (2020). Landscape stories. Visual storytelling on the everyday landscape. In Arena A., Arena M., Brandolino R.G., Colistra D., Ginex G., Mediati D., Nucifora S., Raffa P. (a cura di). Connettere. Un disegno per annodare e tessere. Atti del $42^{\circ}$ Convegno Internazionale dei Docenti delle Discipline della Rappresentazione/Connecting. Drawing for weaving relationships. Proceedings of the 42th International Conference of Representation Disciplines Teachers. Milano: FrancoAngeli, pp. 3025-3042. 